\title{
Application of Isolated Tyrosinase Inhibitory Compounds from Persimmon Leaves
}

\author{
Young-Je Cho ${ }^{1}$, Bong-Jeun $\mathrm{An}^{2}$ and Jeung-Hoan $\mathrm{Kim}^{3}$ \\ ${ }^{1}$ School of Food Science \& Biotechnology, Food \& Bio-Industry Research Institute, Kyungpook National University, Daegu 702-701, Korea \\ ${ }^{2}$ Department of Cosmeceutical, Daegu Hanny University, Gyeongsan, 712-715, Korea \\ ${ }^{3}$ School of Nano Materials Engineering, Kyungpook National University, Sangiu 742-711, Korea
}

Received March 14, 2011 /Revised April 4, 2011 /Accepted April 7, 2011

\begin{abstract}
Total phenolic content was the highest in $60 \%$ ethanol extracts at $21.91 \mathrm{mg} / \mathrm{g}$, and inhibitory activity against tyrosinase of $60 \%$ ethanol extracts was higher than ethanol extracts of other concentration. The inhibitory compounds against tyrosinase from Persimmon leaves were purified using Sephadex LH-20, MCI-gel CHP-20 column chromatography with gradient elution. Two purified compounds were isolated as a result. The chemical structures of each compound were determined and identified using ${ }^{1} \mathrm{H}-\mathrm{NMR}$ and ${ }^{13} \mathrm{C}-\mathrm{NMR}, \mathrm{FAB}-\mathrm{Mass}$. The compounds were confirmed as $(+)$-gallocatechin and prodelphinidin B-3. The tyrosinase inhibitory activities of purified $(+)$-gallocatechin and prodelphinidin B-3 were 29.5 and $40.2 \%$, respectively. The inhibitory activities of (+)-gallocatechin and prodelphinidin B-3 against melanin biosynthesis in melanoma cell were 32.5 and $46.7 \%$. The safety of essence with tyrosinase inhibitory compounds from persimmon leaves was also assessed by various safety profiles. First, changes in $\mathrm{pH}(4.90 \sim 4.95)$ and viscosity $(23,000 \sim 26,000 \mathrm{cP})$ was not detected for 60 days. Essence also showed stability against temperature and light for 60 days. All these findings suggest that extracts from persimmon leaves have a great potential as a cosmetical ingredient with a potent whitening effect.
\end{abstract}

Key words : Application, tyrosinase inhibition, phenolics, persimmon leaves

\section{서 론}

최근에 피부 흑화의 생물학적 현상에 대한 이해가 높아짐에 따라 여러 가지 미백자원에 대한 연구가 가능해졌다. 이에 우 리나라와 일본을 비롯하여 동양권 시장에서 경쟁을 원하는 다국적 기업들을 중심으로 새로운 표적에 작용하는 미백제의 연구가 활발히 진행되고 있으며[23,32], 우리나라에서는 화장 품 법 시행과 함께 기능성 화장품의 연구 및 기술개발이 더욱 발전하고 있다. 기능성 화장품은 다른 화장품과 달리 안전성 유효성을 과학적으로 입증하여 관련기관으로부터 허가를 취 득하여야 하는 제품이며, 따라서 소비자들의 효과에 대한 신 뢰성이 높은 제품이다. 미백화장품의 원료개발에 있어 천연원 료에 대한 연구는 우리 전통의학에 기반을 둔 원료개발이라는 점과 우리나라 소비자들의 화장품 선호도와 맞물려 국내 화장 품 개발의 주력분야가 되고 있으며, 우리가 경쟁력을 확보할 수 있는 부분이므로 지속적인 개발이 필요하다.

피부의 색조를 결정하는 주요한 인자인 melanin은 표피 기 저층의 melanocyte라고 불리는 색소세포 내의 melanosome에 서 생합성 된다. 멜라닌 생합성의 시작물질인 tyrosine은 멜라 닌 세포내에서의 tyrosinase에 의해 DOPA, DOPA quinone을 거쳐 indole-5,6-quinone으로의 중합에 의해 melanin을 생성

*Corresponding author

Tel : +82-53-950-7755, Fax : +82-5-950-7762

E-mail : yjcho@knu.ac.kr
하는 것으로 알려져 있다[24,33,34]. 또한 사람의 피부색을 결 정하는 가장 중요한 요인인 멜라닌(melanin)은 피부의 광노화 나 일광각화증을 억제할 뿐만 아니라[4,29], 기미, 주근깨, 검버 섯 등의 부분적인 hyperpigmentation을 일으키는 역할을 하 고 있다[11,39]. 멜라닌은 표피 기저층에 존재하는 melanocyte 내의 소기관인 melanosome에서 생합성되며, melanocyte의 수지상 돌기를 통하여 주위의 keratinocyte로 전달되고, 피부 의 각질층으로 이행한다[28]. 상기의 색소 침착을 치유하기 위 해 멜라닌 생성을 억제하는 hydroquinone, resorcinol 등의 페 놀 유도체나, L-ascorbic acid와 그 유도체 및 kojic acid, arbutin, lactic acid, glucosamine, tunicamycin 등이 개발되었으나, 피부 자극이나 안정성에 문제가 있어 극히 제한된 양만 사용 되고 있다[6,19].

감의 과육과 잎에 많은 양이 들어 있는 polyphenol 중 탄닌 의 성상은 널리 알려져 있는데 그 중에서도 탄닌의 특징인 단백질 및 금속이온과의 결합에 관해서는 그 응용을 포함하여 연구가 진행되어 왔으며[7], 효소활성의 저해 작용도 중요한 탄닌의 역할로 인식되어지고 있다[36,37]. Feudenberg [12]와 Haslam [14]에 의해 분류된 축합형 탄닌 은 flavan-3-ol 유도체로서는 (-)-epicatechin, $(+)$-catechin 등이 가장 많으며 강산으로 처리하면 anthocyanidin류를 생성하므 로 proanthocyanidin으로 총칭되고 있다[9]. Namba 등[30]은 86종의 생약에서 수종의 flavonol 및 flavonoid 성분을 분리하 여 보고하였다. 최근 식물에 함유되어 있는 생리활성 성분에 
대한 관심이 높아져 이들 생리활성 성분을 함유한 천연식물 소재들을 천연 항산화제와 항진균제의 원료로 이용하려는 시 도가 많이 이루어지고 있다. 식품에 존재하는 생리활성 물질 의 대부분은 페놀성 화합물이고 이들 페놀성 화합물은 일반적 으로 수용성이며 플라보노이드 류가 주를 이루고 단순한 페놀 류, 페놀산, 페닐 프로파노이드 류, 페놀성 퀴논 류들을 포함하 는 것으로 항균, 항알러지, 항산화, 항종양, 항암, 충치방지, 심장질환 및 당뇨병 예방 등의 효과가 있는 것으로 보고되고 있다 [8,13,17].

따라서 각종 생리활성 물질로서 주목받고 있는 탄닌의 tyrosinase 저해활성을 이용한 미백화장품으로 개발하기 위하여 떫은 감잎으로부터 분리한 tyrosinase 저해활성을 갖는 탄닌 을 분리, 동정하고 화장품제조에 적용하여 보았다.

\section{재료 및 방법}

\section{실험 재료}

본 실험에 사용한 감나무잎은 경북상주소재의 감 농장에서 수확하여 건조 후 분쇄하여 저온저장 하면서 이용하였다.

\section{감잎추출물의 조제}

감잎 분말 $1 \mathrm{~g}$ 을 물과 $60 \%$ ethanol $100 \mathrm{ml}$ 에 넣고 6시간 동안 추출한 후 상징액을 Whatman No. 1 로 여과하여 여액을 시료로 사용하였다.

\section{Phenol성 화합물 정량}

시료 $1 \mathrm{ml}$ 를 $95 \%$ ethanol $1 \mathrm{ml}$ 와 증류수 $5 \mathrm{ml}$ 를 첨가하고 $1 \mathrm{~N}$ Folin-ciocalteu reagent $0.5 \mathrm{ml}$ 를 넣어 잘 섞어주고, 5 분간 방치한 후, $\mathrm{Na}_{2} \mathrm{CO}_{3} 1 \mathrm{ml}$ 를 가한 후, 흡광도 $725 \mathrm{~nm}$ 에서 1 시간 이내에 측정하여 gallic acid를 이용한 표준곡선으로 양을 환산 하였다.

\section{Tyrosinase 저해활성 측정}

Tyrosinase 저해활성 측정은 Yagi 등의 방법[38]에 따라 측 정하였다. 반응구는 $0.175 \mathrm{M}$ sodium phosphate buffer $(\mathrm{pH}$ 6.8) $0.5 \mathrm{ml}$ 에 $10 \mathrm{mM} \mathrm{L-DOPA}$ 를 녹인 기질액 $0.2 \mathrm{ml}$ 및 시료용 액 $0.1 \mathrm{ml}$ 의 혼합액에 mushroom tyrosinase ( $110 \mathrm{unit} / \mathrm{ml}) 0.2$ $\mathrm{ml}$ 을 첨가하여 $25^{\circ} \mathrm{C}$ 에서 2 분간 반응시켜 반응액 중에 생성된 DOPA chrome을 $475 \mathrm{~nm}$ 에서 측정하였다. Tyrosinase 저해활 성은 시료용액의 첨가구와 무첨가구의 흡광도 감소율로 나타 내었다.

$$
\text { 저해율 }(\%)=\left(1-\frac{\text { 시료첨가군의 흡광도 }}{\text { 대조구의 흡광도 }}\right) \times 100
$$

Melanoma cell (B16F10)에서의 melanin 생합성 저해

\section{율 측정}

피부 멜라노마 세포로부터의 melanin 생합성 저해 측정은 Hosoi 등[16]의 방법에 따라 측정하였다. DMEM 배지로 배양 된 멜라노마 세포를 $100 \mathrm{~mm}$ culture dish에 $2 \times 10^{6} \mathrm{cell} / \mathrm{dish}$ 가 되게 분주하고 24 시간 배양 후 시료를 농도별로 조제하여 2 $\mathrm{ml}$ 첨가하고, 48 시간 후에 인산완충액 $(\mathrm{pH}$ 7.4)으로 세척하였 다. 그 다음 $0.25 \mathrm{M}$ trypsin-EDTA 용액으로 세포를 탈착한 후 수확한 세포를 $1 \times 10^{6}$ 세포 당 $1 \mathrm{ml}$ 의 $5 \% \mathrm{TCA}$ 로 처리하고, $2,500 \mathrm{rpm}$ 으로 2 회 원심분리한 후 분리된 melanin을 인산완 충액으로 세척한 뒤 ether:ethanol (1:3) $1 \mathrm{ml}$ 를 가하여 2회 원 심분리 한 후 ether $1 \mathrm{ml}$ 로 세척 건조시켰다. 건조된 melanin 에 $1 \mathrm{~N} \mathrm{NaOH}$ 를 $1 \mathrm{ml}$ 가하여 $80^{\circ} \mathrm{C}$ 에서 1 시간 반응시킨 후 분 광 광도계 $405 \mathrm{~nm}$ 에서 흡광도를 측정하였다. Melanin 생합성 저해는 시료용액의 첨가구와 무첨가구의 흡광도 감소율로 나 타내었다.

Melanin 생합성 저해율 $(\%)=\left(1-\frac{\text { 시료첨가군의 흡광도 }}{\text { 대조구의 흡광도 }}\right) \times 100$

\section{Phenol성 화합물의 정제}

\section{Sephadex $\mathrm{LH}-20$ 에 의한 정제}

Sephadex LH-20 column을 충진한 후 흡착성의 성질에 의 해 분리하였다. 용출용매는 normal phase type으로서 $\mathrm{EtOH}$ $\rightarrow \mathrm{H}_{2} \mathrm{O}$ 및 $60 \% \mathrm{EtOH}$ 과 reverse phase type으로 $\mathrm{H}_{2} \mathrm{O} \rightarrow \mathrm{EtOH}$ 의 순으로 용출시켜 TLC 상에서 phenol성 물질의 유무 및 종류를 확인하고 농축, 건조하였다.

\section{MCI-gel CHP 20P에 의한 정제}

MCI-gel은 다공성 polystyren gel로서 흡착성을 이용하였 으며 용출용매는 일반적인 reverse phase type인 $\mathrm{H}_{2} \mathrm{O} \rightarrow \mathrm{EtOH}$ 로 용출하여 TLC 상에서 확인하였다.

\section{Thiolysis}

Nonaka 등[31]의 방법에 따라 시료 $200 \mathrm{mg}$ 을 AcOH-EtOH $(10 \mathrm{ml})$ 에 용해하고 benzylmercaptan $6 \mathrm{ml}$ 를 첨가한 후 reflux 상태에서 6 시간 동안 완전 thiolysis하였다. 반응생성물은 Sephadex LH-20 column으로 $60 \% \mathrm{MeOH}$ 및 $\mathrm{EtOH}$ 을 사용하 여 반복 정제하여 2 종류의 분해물을 얻었다.

\section{Desulfurization}

Nonaka 등[31]의 방법에 따라 시료 $100 \mathrm{mg}$ 을 $10 \%$ $\mathrm{AcOH}-\mathrm{EtOH}(3 \mathrm{ml})$ 에 용해하고 Raney nikel ethanol slurry에 첨가하여 실온에서 2 시간 방치하였다. 방치 후 침전된 Raney nikel을 여과하고 감압 농축하여 Sephadex LH-20 column에 서 $\mathrm{E} \mathrm{tOH}$ 로 정제하였다.

\section{정제된 phenol성 화합물의 물리 및 화학적 성질}

Infrared (IR) spectrum은 할로겐화 알칼리 정제법을 이용 하여 순수 분리된 시료 $1 \mathrm{mg}$ 을 $\mathrm{KBr} 100 \mathrm{mg}$ 분말과 잘 섞어 
배합한 후 가압 정제를 만들어 측정하였다. 핵자기 공명 분광 기(Nuclear Magnetic Resonance, NMR) spectrum은 FT방법 (Pulse Fourier Transform method)을 이용하여 정제물 $10 \mathrm{mg}$ 을 측정용매 $\mathrm{CDCl}_{3}+\mathrm{DMSO}_{-} \mathrm{D}_{6}+\mathrm{D}_{2} \mathrm{O}$ 에 $5 \sim 20 \%(\mathrm{~W} / \mathrm{V})$ 비율로 용해시키고 TMS [Tetramethylsilane; $\left(\mathrm{CH}_{3}\right)_{4} \mathrm{Si}$ ] 를 기준 물질로 하여 PMR $(300 \mathrm{MHz})$ 로 측정하였다. Mass spectrum 측정은 고체 시료 $1 \mathrm{mg}$ 을 감압상태 $\left(10^{-4} \sim 10^{-6} \mathrm{mmHg}\right)$ 에서 negative ion FAB-mass spectrum을 이용하여 화학적 분석법에 의해 측정하였다. 이때 측정 용매로서는 thioglycerol을 사용하였으 며, 측정조건에서 emitter 전류는 $22 \sim 28 \mathrm{eV}$ 이며, 이온원의 가 속가압이 6 7 KV에서 질량분석을 하였다.

\section{감나무잎 추출물을 활용한 화장품(essence)의 제조}

Essence제품의 제조는 수상에 보습제인 glycerin, polyethylene glycol 1500 과 방부제를 넣어 $80^{\circ} \mathrm{C}$ 까지 가열하여 용 해시킨 후, homo mixer (T.K. Homo Mixer Mark I, Tokushu kika kogyo Co. Ltd., Osaka, Japan)를 이용하여 3,000 rpm에 서 2분간 유화하고, 미리 분산한 lubrajel DV와 점증제인 carbopol 940을 넣고 2분간 유화하였다. Triethanolamine (TEA) 를 넣고 3분간 더 유화한 후, 에탄올상인 PEG-40 hydrogenated castor oil을 넣어 2 분간 유화한 후 $30^{\circ} \mathrm{C}$ 까지 냉각하고 탈기하여 제조하였다.

\section{감나무잎 추출물을 활용한 화장품의 안정성 실험}

$\mathrm{pH}$ 측정은 Metrohm (Metrohm 691, Metrohm UK Ltd. Herisau, Switzerland)을 이용하여 $25 \pm 1^{\circ} \mathrm{C}$ 에 보관한 essence 를 측정하였다. 점도측정은 Brookfield Viscometer를 이용하 여 스핀들(spindle) No. 4 를 택하여 $6 \mathrm{rpm}$ 에서 1분간 점도를 측정하였다. 화장품의 온도에 따른 안성성 시험법은 소정의 온도 조건 $\left(0,25,40^{\circ} \mathrm{C}\right)$ 에 보관하여, 경시적 변화에 따른 유분 리, 침전, 변색 등의 상태변화를 관찰하였다. 인공광 노출 시험 은 투명용기에 화장품을 담아 sun lamp 장치(내부온도는 $40^{\circ} \mathrm{C}$, 광원과 용기의 거리는 $20.3 \mathrm{~cm}$ )에 넣은 후 인공 UV 조사 후 $0.5,1,2,3$ 시간 동안의 변색, 발색, 변취, 산패 등의 변화를 관찰하였다. 또한 자연광 노출 시험은 화장품을 투명용기에 담아 햇빛이 잘 드는 실외에 보관하여 7,15 일 동안의 변색, 발색, 변취, 산패 등의 변화를 관찰하였다. 온도순환에 따른 안정성 시험은 화장품을 투명용기에 담아 $-15^{\circ} \mathrm{C},-10^{\circ} \mathrm{C},-5^{\circ} \mathrm{C}$, $0^{\circ} \mathrm{C}, 5^{\circ} \mathrm{C}, 10^{\circ} \mathrm{C}, 15^{\circ} \mathrm{C}, 25^{\circ} \mathrm{C}, 37.5^{\circ} \mathrm{C}, 40^{\circ} \mathrm{C}$ 에서 각각 24 시간 보관 한 후 이를 1 cycle로 하여 10회 반복 시행하여 온도 순환에 따른 안정성을 평가하였다(Fig. 4). 냉·해동순환(freeze \& thaw cycling)에 따른 안정성 시험은 화장품을 투명용기에 담 아 $-10^{\circ} \mathrm{C}$ 와 $25^{\circ} \mathrm{C}$ 에 각각 24 시간 보관하여 이를 $1 \mathrm{cycle}$ 로 하여 3,7 일 동안의 안정성을 관찰하였다.

\section{결과 및 고찰}

\section{Ethanol 농도에 따른 phenol성 물질의 용출량}

감나무잎 추출물의 추출 조건을 확립하기 위해 다양한 농도 의 ethanol을 추출용매로 하여 phenol성 물질의 용출량을 측 정하였다. 그 결과 Fig. 1 과 같이 $60 \%$ ethanol을 사용하여 추출 하였을 경우 가장 높은 용출량을 확인 할 수 있었으며, tyrosinase 억제 효과도 $60 \%$ ethanol 추출물에서 가장 높게 나타 나는 것으로 보아 phenol성 물질의 함량과의 상관관계가 인정 되었다. 따라서 이후의 실험은 물 추출물과 $60 \%$ 에탄올 추출 물을 이용하여 실시하였다.

\section{추출물의 tyrosinase 억제 효과 측정}

Tyrosinase는 tyrosine으로부터 3,4-dihydroxyphenylalanine 과 DOPA-quinone을 거쳐 최종적으로 흑갈색의 melanin 색소 생성에 관계하는 효소로써 야채나 과실류 특히 감자의 갈변현 상과 피부에 암갈색의 색소 물질을 침착 시키는 원인이 되기 도 한다. 본 연구에서는 식물 유래 추출물로부터 미백 및 갈변 저해물질을 분리하고 미백효과를 검토하여 기능성 화장품 소 재로서 활용키 위해 tyrosinase 억제효과를 검토한 결과 Fig. 2에서와 같이 감잎 $60 \%$ 에탄올 추출물에서 약 $37 \%$ 의 tyrosinase 억제효과를 나타내어 가장 높은 저해효과를 확인할 수 있었다. 그리고 전체적으로 물 추출물보다는 에탄올 추출 물이 tyrosinase 저해활성이 높은 것을 확인할 수 있었다. Tyrosinase 저해활성은 폴리페놀의 종류 및 그 구조와 상관관 계가 있는 것으로 $\mathrm{Kim}$ 등[22]은 보고하였고, 또한 폴리페놀 중에서도 catechin류는 tyrosinase 저해활동을 나타내지 않았 지만, gallocatechin이나 epicatechin류에서 높은 저해활성을 나타내었으며, monomer보다 dimer에서 저해활성이 더 우수 하였다고 안 등[1]은 보고하였다.

\section{감잎 추출물로부터 tyrosinase 저해 물질의 정제 및 동정}

Tyrosinase 저해 활성 측정 결과 감잎 추출물에서 $37 \%$ 의

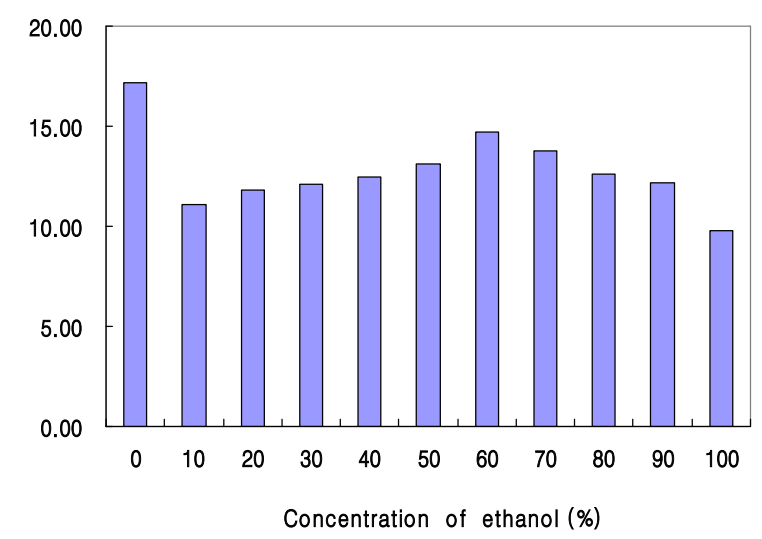

Fig. 1. The effect of ethanol concentration on phenolics content in extracts from Persimmon leaves. 


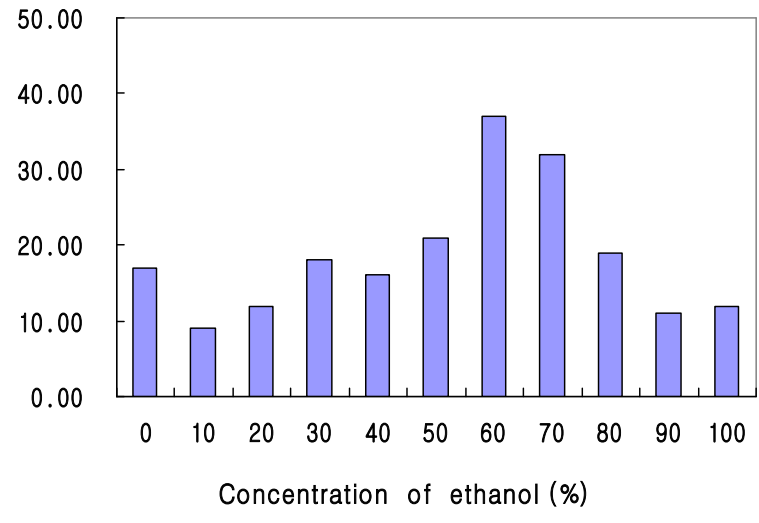

Fig. 2. Inhibition of tyrosinase activity by extracts from Persimmon leaves.

저해력을 나타내어 감잎으로부터 효소활성 저해 물질로 생각 되어지는 화합물인 polyphenol류를 정제하고자 하였다. 감잎 을 $60 \% \mathrm{EtOH}$ 로 추출하여 농축하고 Sephadex LH-20 column 에 충진하여 $60 \% \mathrm{EtOH}$ 을 용매로 하여 용리한 결과 Fig. 3과 같이 3 가지 분획물을 얻을 수 있었으며, 세가지 분획 중 $\mathrm{B}$ 분획 에서 효소 저해 활성이 확인되어(Table 1), Sephadex LH-20 column을 이용하여 $\mathrm{EtOH}$ 을 $0 \rightarrow 100 \%$ 까지 변화시키며 2차 분리를 수행한 결과 B분획에서 3 가지(B-1, B-2, B-3)분획이 검 출되었고, $\mathrm{C}$ 분획에서 2가지(C-1, C-2)분획이 검출되었다. 이들 분획 중 B-2와 C-1에서 tyrosinase 저해활성이 검출되었으나 (Table 2), TLC 상에서 혼합물로 판정되어 순수물질로 분리하 기 위하여, B-2와 C-1을 MCI-gel CHP-20 column을 이용하여 3 차 분리 하였다. 이때 용리 조건은 $\mathrm{MeOH}$ 을 $0 \rightarrow 100 \%$ 로 gradient로 용출하였다. 그 결과 Fig. 3에서와 같이 B-2로부터 B-2-1와 B-2-2을, C-1으로 부터 C-1-1, C-1-2 및 C-1-3의 단일 물질을 얻을 수 있었으며, 각 정제물을 이용하여 tyrosinase저

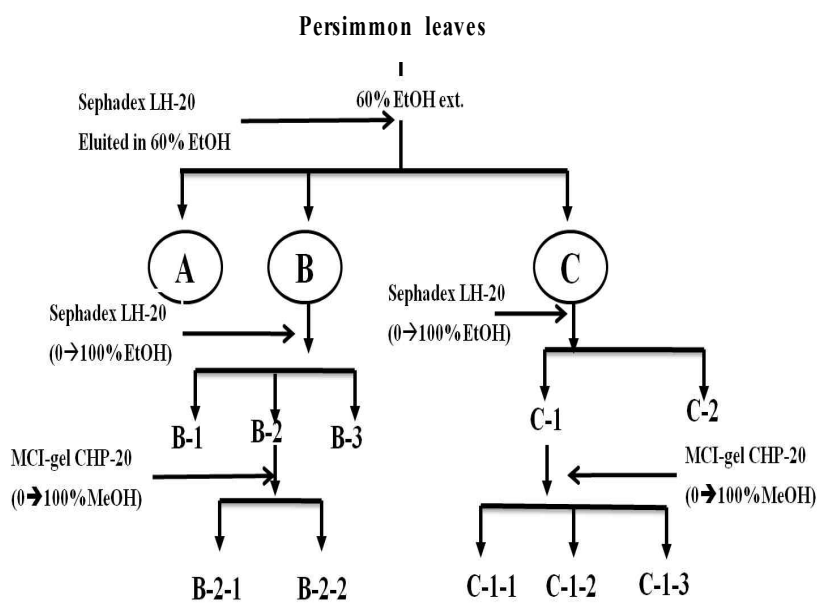

Fig. 3. A procedure for isolation of phenolic compounds from persimmon leaves.
Table 1. Tyrosinase inhibition of fractions from persimmon leaves by Sephadex LH-20

\begin{tabular}{cc}
\hline Fraction & Inhibition activity $(\%)$ \\
\hline A & - \\
B & $26.5 \pm 2.3$ \\
C & $38.3 \pm 1.5$ \\
\hline
\end{tabular}

Table 2. Tyrosinase inhibition fractions from persimmon leaves by Sephadex LH-20

\begin{tabular}{cc}
\hline Fraction & Inhibition activity $(\%)$ \\
\hline B-1 & - \\
B-2 & $28.3 \pm 3.3$ \\
B-3 & - \\
\hline C-1 & $37.9 \pm 3.5$ \\
C-2 & - \\
\hline
\end{tabular}

해 활성을 측정한 결과 B-2-2(compound A)와 C-1-2(compound B)에서 높은 효소 저해 활성을 확인할 수 있었다(Table 3). 정제된 2가지 compound의 동정을 위하여 구조 분석을 한 결과, compound $\mathrm{A}$ 는 무색침상형으로 melting point가 186 $189^{\circ} \mathrm{C}$ 이었고, $[\mathrm{a}]_{\mathrm{D}}$ 가 $+2.4^{\circ}(\mathrm{C}=1.0$, acetone $)$ 이었으며, negative FAB-MS에서 305의 분자량을 얻었으므로 (-)-epicatechin 및 $(+)$-catechin에 산소 분자 1 개가 더 결합한 물질임을 알 수 있 었고, ${ }^{1} \mathrm{H}-\mathrm{NMR}$ spectrum에서 $2.56 \mathrm{ppm}(\mathrm{dd}), 2.75 \mathrm{ppm}(\mathrm{dd})$ 는 alipatic 영역의 4-H를 의미하고 $4.13 \mathrm{ppm}(\mathrm{s}), 4.74 \mathrm{ppm}(\mathrm{d})$ 은 catechol의 전형적인 signal로써 3,2-H를 확인할 수 있었다. 또 한 5.86, $5.99 \mathrm{ppm}$ spectrum은 doublet의 분열 양상으로 $6,8-\mathrm{H}$ 임을 시사하였고 $6.52 \mathrm{ppm}$ 의 $2 \mathrm{H}$ 분의 singlet는 2',6'-H로서 (+)-gallocatechin으로 동정하였다. 이러한 결과는 Sakanaka 등[35]의 분석 결과와 일치하였다. Compound $\mathrm{B}$ 는 염갈색의 무정형으로 $[\mathrm{a}]_{\mathrm{D}}$ 는 $-157.6^{\circ}(\mathrm{C}=1.0$, acetone)이었고 anisaldehyde- $\mathrm{H}_{2} \mathrm{SO}_{4}$ 에서 갈색반응을 나타내었으며, negative FAB-MS에서 m/z; 609[M-H]'의 분자량을 얻었으므로 축합형 탄닌의 dimeric 이상의 화합물임을 알 수 있었다. Compound $\mathrm{B}$ 를 monomer로 제조하기 위해 thiolysis반응을 거쳐 Sephadex LH-20 column으로 분리한 결과 Fig. 4에서와 같이 compound B-1과 B-2가 1:1 mol의 비율로 얻어 졌으며 B-1의 ${ }^{1} \mathrm{H}-\mathrm{NMR}$ spectrum을 확인한 결과 $4.09 \mathrm{ppm}\left(2 \mathrm{H}, \mathrm{s},-\mathrm{SCH}_{2}-\right)$, 7.16 7.46 ppm (5 H, aromatic)에서 benzylthioether화된 물

Table 3. Tyrosinase inhibition fractions from persimmon leaves by Sephadex LH-20

\begin{tabular}{cc}
\hline Fraction & Inhibition activity $(\%)$ \\
\hline B-2-1 & $5.2 \pm 0.8$ \\
B-2-2 & $29.5 \pm 1.3$ \\
\hline C-1-1 & $1.3 \pm 0.3$ \\
C-1-2 & $40.2 \pm 1.3$ \\
C-2-3 & $10.7 \pm 1.1$ \\
\hline
\end{tabular}




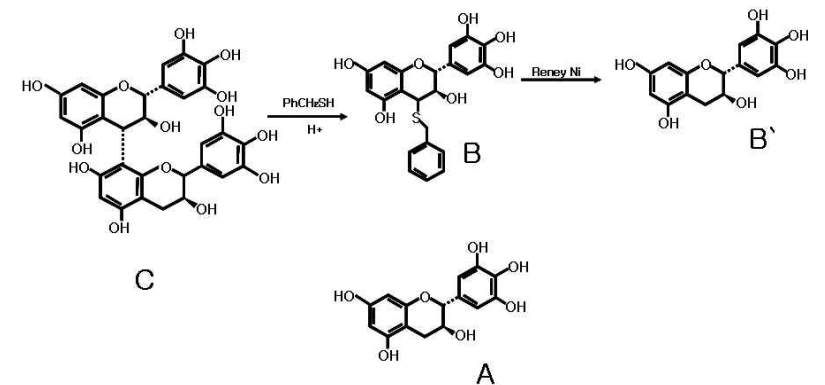

(Prodelphinidin B-3)

Fig. 4. Thiolysis of compound C-1-2

질로 확인 되었고, 다시 물질의 확실한 귀속을 위하여 Raney $\mathrm{Ni}$ 하에 탈황 반응을 거쳐 Sephadex LH-20으로 정제한 결과 B-3를 얻을 수 있었다. B-3의 ${ }^{1} \mathrm{H}-\mathrm{NMR}$ 을 살펴본 결과 compound $\mathrm{A}$ 의 ${ }^{1} \mathrm{H}-\mathrm{NMR}$ 과 일치하여 (+)-gallocatechin으로 동정 하였으며 B-2의 ${ }^{1} \mathrm{H}-\mathrm{NMR}$ 도 (+)-gallocatechin의 signal과 일치 하였다. 또한 compound $\mathrm{B}$ 물질의 spectrum에서 상부에 해당 하는 $4-\mathrm{H}$ 의 결합정수가 크므로 compound $\mathrm{B}$ 는 상부에 $(+)$-gallocatechin, 하부에 (+)-gallocatechin이 4a-8의 결합형태 로 결합된 prodelphinidin B-3로 동정하였다. 이러한 결과는 안 등[1,2,3]의 결과와 일치하였다.

\section{정제물의 tyrosinase 저해활성 확인}

Tyrosinase는 피부 멜라닌 생성에 있어서 매우 중요한 역할 을 하고 있으며, melanosome 내에서 tyrosine을 산화시켜 $\mathrm{DOPA}$ 를 만드는 tyrosine hydroxylase로, $\mathrm{DOPA}$ 를 산화시켜 DOPA quinone을 만드는 DOPA oxidase로서 작용하여 멜라 닌 중합체를 합성하는데 중요한 효소로 작용한다[15]. 이렇게 피부 내에서 멜라닌 중합체 생합성을 효과적으로 저해할 수 있는 tyrosinase 저해활성을 측정한 결과 Table 4 와 같이 측정 되었다. 감잎으로부터 분리한 (+)-gallocatechin과 prodelphinidin B-3는 각각 $29.5,40.2 \%$ 의 저해활성을 나타내어 tyrosinase 저해활성이 비교적 높게 나타났다. Lee 등[27]의 제주 산 식물을 이용한 tyrosinase 억제 활성을 측정한 결과 1,000 $\mathrm{ppm}$ 의 농도에서 $10.0 \%$ 미만의 효과가 나타났으며, Jung 등 [20]의 토사자, 숙지황, 오가피 추출물 1,000 ppm에서 $30.0 \%$ 미만의 저해능을 나타낸 결과와, $\mathrm{An}$ 등[5]의 진달래꽃 추출물 의 tyrosinase 저해활성을 측정한 결과 열수 및 에탄올 추출물 $1,000 \mathrm{ppm}$ 에서 각각 $24.0,48.0 \%$ 의 저해를 나타낸 결과와 비교

Table 4. Inhibitory effect of tyrosinase by purified phenolics from persimmon leaves

\begin{tabular}{|c|c|c|}
\hline Source & Phenolics & Inhibition activity (\%) \\
\hline Persimmon & Gallocatechin & $29.5 \pm 1.3$ \\
\hline leaves & Prodelphinidin B-3 & $40.2 \pm 2.6$ \\
\hline
\end{tabular}

하여 감잎의 활성이 우수함을 확인할 수 있었다. 또한 Kwak 등[26]의 쑥 추출물의 tyrosinase 저해활성을 측정한 결과 10 $\mathrm{mg} / \mathrm{ml}$ 에서 hexane, chloroform 및 ethyl acetate로 분획한 추 출물이 각각 $55.8,57.5,60.2 \%$ 의 효과를 나타내었으며, Kwak 등 [25]이 치자열매의 에탄올 추출물을 hexane, chloroform 및 ethyl acetate로 분획한 치차열매 분획물의 tyrosinase 저해능 이 $10 \mathrm{mg} / \mathrm{ml}$ 에서 $72.0 \%, 59.0 \%, 99.7 \%$ 를 나타내었다고 보고 한 것과 유사한 저해활성을 나타내어 tyrosinase 저해활성이 우수함을 확인할 수 있었다.

\section{Melanoma cell (B16F10)에서의 melanin 생합성 저해 율 확인}

감잎 정제물을 천연 미백제로 사용하기 위하여 melanoma 세포에서의 멜라닌 생합성을 측정한 결과 Table 5 와 같이 측정 되었다. 감잎으로부터 분리한 (+)-gallocatechin과 prodelphinidin B-3는 멜라닌생성 저해효과가 각각 $32.5,46.7 \%$ 의 저해 활성을 나타내었다. 이는 Kwak 등[25]의 치자 열매 추출물의 B16F10 melanoma 세포의 melanin 억제효과가 $10 \mathrm{mg} / \mathrm{ml}$ 에 서 열수 추출물의 경우 $36.3 \%$, 에탄올 추출물의 경우 $55.9 \%$ 로 나타나 감잎의 멜라닌 생성억제효과와 비슷함을 알 수 있었 고, Hwang 등[18]의 인삼의 부위별 멜라닌 생성억제효과에서 건조 인삼시료 $100 \mathrm{\mu g} / \mathrm{ml}$ 의 농도에서 $27.0 \%$ 의 저해율을 나타 내었으며, Cho 등[10]의 유기농의 멜라닌 생성 억제 효과에서 $200 \mathrm{\mu g} / \mathrm{ml}$ 의 유기농 butanol 분획물의 경우 $25.0 \%$ 의 저해율 을 나타내었고, Kim 등[21]의 안정화시킨 vitamin C와 파이토 스핑고신의 멜라닌 생성 억제 효과에서 대조군인 코직산이 $100 \mathrm{\mu g} / \mathrm{ml}$ 의 농도에서 $44.7 \%$ 의 억제효과와 비교하여, 감잎의 멜라닌 저해 효과가 우수함을 확인할 수 있었으며, 우수한 천 연 미백제로 사용이 가능할 것으로 사료된다.

\section{감나무잎 추출물을 활용한 essence 제품의 안정성}

Table 6 의 처방에 따라 제조하여 실온 $\left(25^{\circ} \mathrm{C}\right)$ 에서 보관한 essence 제품을 60 일간의 $\mathrm{pH}$ 와 점도 측정 결과 Fig. 5 와 같았다. Essence 제품의 경우 $10,000 \mathrm{ppm}$ 의 농도에서 $\mathrm{pH}$ 측정결과 4.90 4.95로 60 일 동안의 저장기간 동안 큰 변화를 나타내지 않았다. Essence 제품의 점도를 Brookfield LV-II digital viscometer로 측정한 결과 실온 $\left(25^{\circ} \mathrm{C}\right)$ 에서 보관한 essence 제품의 점도를 60 일 동안 측정한 결과 $23,000 ~ 26,000 \mathrm{cP}$ 사이에 분포 했으며 저장기간 동안 수치상의 큰 변화 없이 안정하였다. 화 장품의 열에 의한 경시적 품질열화현상을 관찰하기 위해서

Table 5. Inhibitory effects of melanin synthesis of purified compounds from persimmon leaves induced B-16 mouse melanoma cell lines

\begin{tabular}{|c|c|c|}
\hline Source & Phenolics & Inhibition activity (\%) \\
\hline Persimmon & Gallocatechin & $32.5 \pm 2.3$ \\
\hline leaves & Prodelphinidin B-3 & $46.7 \pm 1.1$ \\
\hline
\end{tabular}


Table 6. Recipe of essence

\begin{tabular}{|c|c|c|}
\hline Phase & Ingredient & Content $(\%)$ \\
\hline \multirow{8}{*}{ A } & Purified Water & 37.75 \\
\hline & Dopotassium Glycyrrhizate & 0.05 \\
\hline & Disodium Ethylenediaminetetraacetate & 0.03 \\
\hline & Imidazolidynyl Urea & 0.15 \\
\hline & Polyethylene Glycol 1500 & 2.00 \\
\hline & Betain & 3.00 \\
\hline & Glycerin & 5.00 \\
\hline & 1,3-Butylene Glycol & 2.00 \\
\hline \multirow{2}{*}{$\mathrm{B}$} & Purified Water & 10.00 \\
\hline & Polyglycerylmethacrylate/Propylene Glycol & 2.00 \\
\hline \multirow{3}{*}{$\mathrm{C}$} & Purified Water & 15.00 \\
\hline & Carbomer 940 & 0.20 \\
\hline & Carbomer 941 & 0.06 \\
\hline \multirow{2}{*}{$\mathrm{D}$} & Purified Water & 2.00 \\
\hline & Hydroxyethylcellulose & 0.02 \\
\hline \multirow{2}{*}{$\mathrm{E}$} & Purified Water & 1.00 \\
\hline & Sodium Hyaluronate & 0.01 \\
\hline \multirow{2}{*}{$\mathrm{F}$} & Purified Water & 2.00 \\
\hline & Triethanolamine & 0.26 \\
\hline \multirow{4}{*}{ G } & Ethanol & 6.00 \\
\hline & Methyl Paraben & 0.15 \\
\hline & Polyoxyethylene Hydrogenated Castor Oil & 0.40 \\
\hline & Fragrance & 0.02 \\
\hline \multirow{2}{*}{$\mathrm{H}$} & Aloe Vera Gel & 0.30 \\
\hline & Fucogel 1000 & 0.30 \\
\hline \multirow{2}{*}{ I } & Purified Water & 10.00 \\
\hline & Purified compounds & 0.30 \\
\hline
\end{tabular}
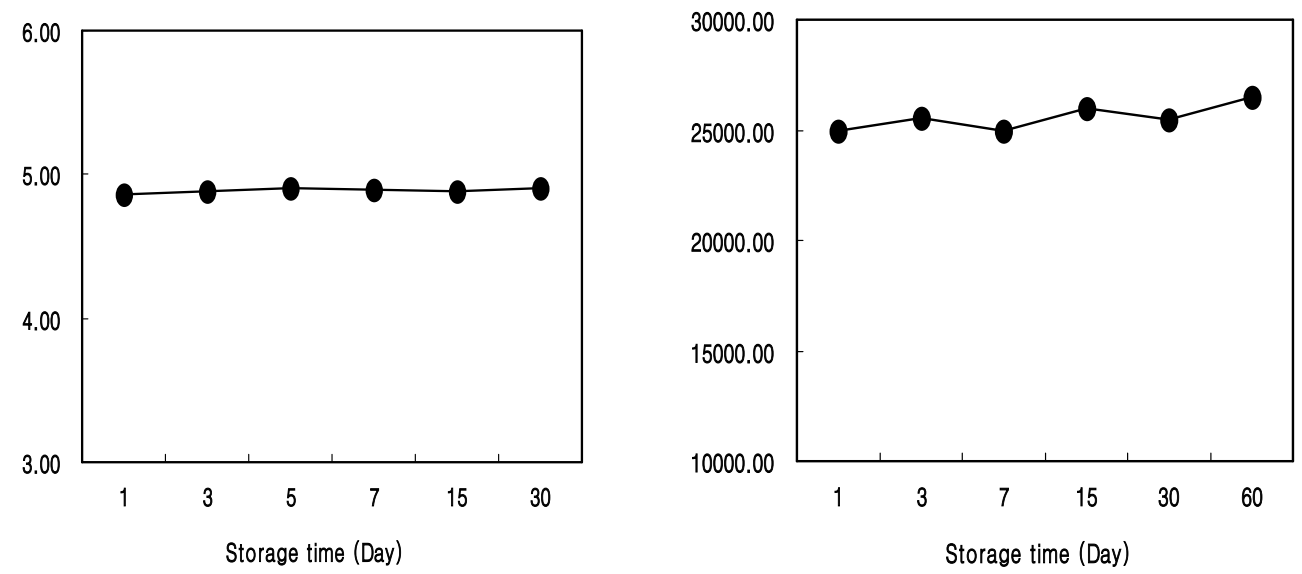

Fig. 5. $\mathrm{pH}$ and viscosity change of the essence.

온도안정성 평가를 실시한 결과 Table 7 과 같이 $0,25,40^{\circ} \mathrm{C}$ 의 온도에서 보관한 essence 제품은 60 일 동안 모든 온도 조건에 서 안정한 것으로 나타났다. 불안정한 화장품의 경우 고온(4 $0^{\circ} \mathrm{C}$ )에서는 외관의 산패, 변색, 변취, 점도, 증발, 부유, 침전, 탁도(투명도), 분리 등이 관찰되며, 저온에서는 응고, 침전, 탁 도(투명도), 결정 석출, 분리 등의 화학적 - 물리적 변화가 관찰
된다. 이와 같은 현상은 사용성에 큰 영향을 줄뿐 아니라, 화장 품이 갖는 미적외관, 이미지의 손실에도 영향을 준다. 일반적 으로 화장품의 품질수명은 소비자가 끝까지 사용할 때 까지를 보증해야 하므로 안정성을 체크해야 하며, essence 제품은 60 일 동안 경시적 변화 없이 안정하였다. Essence 제품의 인공광 과 자연광에 대한 안정성을 실시한 결과 Table 8과 9와 같이 
Table 7. Results of stability test of essence in constant temperature conditions

\begin{tabular}{ccccccc}
\hline & \multicolumn{5}{c}{ Stability } \\
\cline { 2 - 6 } Temperature $\left({ }^{\circ} \mathrm{C}\right)$ & \multicolumn{5}{c}{ Storage time $($ day) } \\
\cline { 2 - 6 } & 1 & 3 & 7 & 15 & 30 & 60 \\
\cline { 2 - 6 } & Stable & Stable & Stable & Stable & Stable & Stable \\
25 & Stable & Stable & Stable & Stable & Stable & Stable \\
40 & Stable & Stable & Stable & Stable & Stable & Stable \\
\hline
\end{tabular}

Table 8. Results of artificial sun lamp test of essence

\begin{tabular}{ccccc}
\hline \multirow{2}{*}{ Condition } & \multicolumn{4}{c}{ Storage time $(\mathrm{hr})$} \\
\cline { 2 - 5 } & 0.5 & 1 & 2 & 4 \\
\hline Stability & Stable & Stable & Stable & Stable \\
\hline
\end{tabular}

* Temperature was $40^{\circ} \mathrm{C}$ and Distance from light source was $20.3 \mathrm{~cm}$

Table 9. Results of sun test of essence

\begin{tabular}{ccc}
\hline \multirow{2}{*}{ Sample } & \multicolumn{3}{c}{ Storage time (day) } \\
\cline { 2 - 3 } & Stable & Stable \\
\hline Essence & & S
\end{tabular}

Table 10. Results of stability test of essence in cycle chamber condition

\begin{tabular}{ccccccccccc}
\hline Cycle & 1 & 2 & 3 & 4 & 5 & 6 & 7 & 8 & 9 & 10 \\
\hline Stability & Stable & Stable & Stable & Stable & Stable & Stable & Stable & Stable & Stable & Stable \\
\hline
\end{tabular}

Table 11. Results of stability test of essence in freeze \& thaw cycling condition

\begin{tabular}{ccc}
\hline Temperature $\left({ }^{\circ} \mathrm{C}\right)$ & 3 & Storage time (day) \\
\cline { 2 - 3 } & Stable & Stable \\
\hline-10 & Stable & Stable \\
\hline
\end{tabular}

저장 기간 동안 모두 안정함을 나타내었다. 이러한 결과로 볼 때 감나무 잎의 미백물질이 첨가된 화장품은 제조 후 태양광 과 형광등의 빛에 노출되어도 비교적 안정성을 유지한다고 판단되었다. 온도순환에 따른 안정성 시험법은 4 계절이 분명 한 우리나라에서 화장품의 저온 및 고온의 보관조건에 따른 물성변화를 관찰하기 위하여 실시하고 있으며, 또한 온도 변 화에 따라 유화-가용화에서의 물성변화를 관찰하기 위하여 실시한다. 제품의 대부분은 고온에서 가수분해 현상 및 기타 현상 등이 빨리 일어나며, 저온인 경우는 부피팽창, 용해도차 에 의한 계면막 손상, 침전 등이 일어난다. Essence 제품을 - 15 , $-10,-5,0,5,10,15,25,37.5,40^{\circ} \mathrm{C}$ 에서 각각 24 시간 보관한 후 온도 순환에 따른 안정성을 관찰한 결과 Table 10 과 같이 10 cycle 모두에서 상의 분리와 변색, 변취 없이 안정함을 육안 으로 확인할 수 있었으며, essence 제품을 급격한 온도 조건인 고온 $\left(25^{\circ} \mathrm{C}\right)$ 과 저온 $\left(-10^{\circ} \mathrm{C}\right)$ 의 온도 변화를 주어 각각 24 시간 보 관하여 3 일과 7 일차에 안정성을 관찰한 결과 Table 11 과 같이
상의 분리와 변색, 변취 없이 모두 안정함을 확인할 수 있었다.

\section{감사의 글}

이 논문은 2010년 경북대학교 학술연구비에 의해 연구되었 으며 이에 감사드립니다.

\section{References}

1. Ahn, B. J., M. J. Bae, and C. Choi, C. 1998. Chemical structure and isolation of glucosyltransferase inhibitor from the Korean persimmon. Food Sci. Biotechnol. 7, 23-27.

2. Ahn, B. J., J. Y. Choi, I. B. Kwon, I. Nishioka, and C. Choi. 1992. Structure and isolation of glucosyltransferase inhibitor from Jack Fruit. Korean Biochem J. 25, 347-352.

3. Ahn, B. J., I. B. Kwon, and C. Choi. 1995. Inhibitory Effect of Novel Flavan-3-ol isolated Theobroma cacao L, Husk on 
glucosyltransferase. Korean J. Food Sci. Technol. 27, 92-98.

4. Akiu, S, Y. Suzuki, T. Asahara, Y. Fujinuma, and M. Fukuda. 1991. Inhibitory effect of arbutin on melanogenesis-biochemical study using cultured B16 melanoma cells. Nippon Hifuka Gakkai Zasshi 101, 609-613.

5. An, B, J, C. E. Lee, J. H. Son, J. Y. Lee, G. H. Choi, and T. S. 2005. Antioxidant, anticancer and tyrosinase inhibition activities of extracts from Rhododendron mucronulatum T. J. Korean Soc. Appl. Biol. Chem. 48, 280-284.

6. Ando, S, O. Ando, Y. Suemoto, and Y. Mishima. 1993. Tyrosinase gene transcription and its control by melanogenic inhibitors. J. Invest Dermatol. 100, 150-155.

7. Armstrong, G. S. 1984. A study of tannin protein interactions. Dissertation Abstracts International 44, 2695-2702.

8. Azuma, K., M. Nakayama, M. Koshika, K. Ippoushi, Y. Yamaguchi, K. Kohata, Y. Yamauchi, H. Ito, and H. Higashio. 1999. Phenolic antioxidants from the leaves of Corchorus olitorius L. J. Agric. Food Chem 47, 3963-3966.

9. Butler, L. G., M. L. Price, and J. E. Brotherton. 1982. Vanillin assay for proanthocyanidins(condensed tannins); Modification of the solvent for estimation of the degree of polymerization. J. Agric. Food Chem 30, 1087-1089.

10. Cho, Y. H., B. C. Lee, J. H. Kim, H. B. Pyo, Y. H. Zhang, and H. D. Park. 2005. Effect of Artemisia anomala S. Moore on antioxidant activity and melanogenesis. Korean J. Pharmacogn. 36, 273-277.

11. Choi, B. W., B. H. Lee, K. J. Kang, E. S. Lee, and N. H. Lee. 1998. Screening of the tyrosinase inhibitors from marine algae and medicinal plants. Korean J. Pharmacogn. 9, 237-242.

12. Freudenberg, K. 1920. "Die chemie der Naturichen Gerbstoff". Springer Verlag, Berlin

13. Ham, S. S., J. K. Hong, and J. H. Lee. 1997. Antimutagenic effects of juices from edible Korean wild herbs. J. Food Sci. Nutr. 2, 155-161.

14. Haslam, E. 1966. "Chemistry of Vegitable Tannins": Academic Press, London and New York

15. Hearing, V. J. and M. Jimenez. 1987. Mammalian tyrosinase the critical regulatory control point in melanocyte pigmentation. Int. J. Biochem 19, 1141-1147.

16. Hosoi, J. E. Abe, T. Suda, and T. Kuroki. 1985. Regulation of melanin synthesis of B16 mouse melanoma cells by 1-alpha, 25-dihydroxyvitamin D3 and retinoic acid. Cancer Res. 45, 1474-1478.

17. Huang, M. T., C. T. Ho, and C. Y. Lee. 1992. Phenolic compounds in food. In phenolc compounds in food and their effects on health II. Maple Press, New York. 99, 2-7.

18. Hwang, E. Y. and S. Y. Choi. 2006. Quantitative analysis of phenolic compounds in different parts of Panax ginseng C.A. Meyer and its inhibitory effect on melanin biosynthesis. Korean J. Medicinal Crop Sci. 14, 148-152.

19. Imokawa, G. and Y. Mishima. 1982. Loss of melanogenic properties in tyrosinase induced by glucosylation inhibitors within malignant melanoma cells. Cancer Res. 42, 1994-2002.

20. Jung, S. W., N. K. Lee, S. J. Kim, and D. S. Han. 1995. Screening of tyrosinase inhibitor from plants. Korean J. Food Sci. Technol. 27, 891-896.
21. Kim, B. J. and B. K. Jo. 1998. A skin protection beauty expenses composite which contains the phytosphingosine with a vitamin $\mathrm{C}$ to relieve. Korea Institute of Patent Information. 10-1998-0058217, p 11.

22. Kim, J. K., W. S. Cha, J. H. Park, S. L. Oh, Y. J. Cho, S. S. Chun, and C. Choi. 1997. Inhibition effect against tyrosinase of condensed tannins from Korean green tea. Korean J. Food Sci. Technol. 29, 173-177.

23. Kligman, D. 2000. Cosmeceuticals. Dermatol. Clin. 18, 609-615.

24. Ko, J. S. 2000. Dermatology. Soomoonsa Press. Seoul. Korea. p73.

25. Kwak, J. H., Y. H. Kim, H. R. Chang, C. W. Park, and Y. H. Han. 2004. Inhibitory effect of gardenia fruit extracts on tyrosinase activity and melanogenesis. Korean J. Biotechnol. Bioeng. 19, 437-440.

26. Kwak, J. H., U. K. Seo, and Y. H. Han. 2001. Inhibitory effect of Mugwork extracts on tyrosinase activity. Korean J. Biotechnol. Bioeng. 16, 220-223.

27. Lee, N. H., H. C. Yang, H. J. Bu, D. S. Jung, S. J. Lee, and K. Z. Riu. 2001. Screening of the tyrosinase inhibition and hyaluronidase inhibition activities and radical scavenging effects using plants in Cheju. Korean J. Pharmacogn. 32, 175180.

28. Lin, C. B., L. Babiarz, F. Liebel, P. E. Roydon, M. Kizoulis, G. J. Gendimenico, D. E. Fisher, and M. Seiberg. 2002. Modulation of microphthal mia-associated transcription factor gene expression alters skin pigmentation. J. Invest Dermatol. 119, 1330-1340.

29. Mishima, Y, S. Hatta, Y. Ohyama, and M. Inazu. 1988. Induction of melanogenesis suppression : Cellular pharmacology and mode of differential action. Pigment Cell Res. 1, 367-374.

30. Namba, T., M. Tsunezuka, Y. Takehara, S. Nunome, T. Takeda, Y. Z. Kakiuchi, K. Kobayashi, S. Takagi, and M. Hattori, M. 1984. Studies on dental caries prevention by traditional chinese medicines(part iv). Screening of crude drugs for anti-plague action and effect of artemisia capillaris spikes on adherence of Streptococcus mutans to smooth surface and synthesis of glucan by glucosyltransferase. Shoyakugaku Zasshi 38, 253-259.

31. Nonaka, G. H., F. L. Hus, and I. Nishioka. 1981. Structure of dimeric, trimeric and tetrameric procyanidins from Areca catechu L. J. C. S. Chem Comm 1, 781-788.

32. Park, S. K., S. N. Kim, J. C. Lee, H. S. Kim, Y. J. Kim, B. G. Lee, and I. S. Chang. 2004. Anti-aging effect on skin with Jaeum-Dan (JED). Kor. J. Herbology 19, 67-76.

33. Pavel, S. and F. A. Muskiet. 1983. Eumelanin(precursor) metabolites as markers for pigmented malignant melanoma, a preliminary report. Cancer Detect Prev. 6, 311-316.

34. Prota, G. 1980. Recent advances in the chemistry of melanogenesis in mammals. J. Invest Dermatol. 75, 122-127.

35. Sakanaka, S., M. J. Kim, and T. Yamamoto. 1989. Antibacerial substances in Japanese green tea extract against Streptococcus mutans a carciogenic bacterium. Agric. Biol. Chem 53, 2307-2312. 
36. Sharma, A. and S. Sehgal. 1992. Effect of domestic processing, cooking and germination on the trypsin inhibitor activity and tannin content of faba bean. Plant Food for Human Nutrition 42, 127-132.

37. Tan, N. H., K. C. Wong, and B. O. Lumen. 1984. Relationship of tannin levels and trypsin inhibitor activity with the in vitro protein digestibilities of raw and heat-treated winged bean. J. Agric. Food Chem 32, 819-823.

38. Yagi, A., T. Kanbara, and N. Morinobu. 1986. The effect of tyrosinase inhibition for aloe. Planta Medica 3981, 517-519.

39. Yamamura, T., J. Onishi, and T. Nishiyama. 2002. Antimelanogenic activity of hydrocoumarins in cultured normal human melanocytes by stimulating intracellular glutathione synthesis. Arch Dermatol. Res. 294, 349-354.

\section{초록 : 감나무 잎으로 부터 분리한 tyrosinase 억제물질의 응용}

\section{조영제 ${ }^{1} \star$. 안봉전 ${ }^{2} \cdot$ 김정환 ${ }^{3}$}

( ${ }^{1}$ 경북대학교 식품공학부, 식품생물산업연구소, ${ }^{2}$ 대구한의대학교 화장품약리학과, ${ }^{3}$ 경북대학교 나노소재공 학부)

감잎으로부터 tyrosinase 억제물질의 추출을 위하여 $60 \%$ ethanol을 사용하여 추출한 경우 추출물의 phenol성 물질 함량이 $21.91 \mathrm{mg} / \mathrm{g}$ 로 가장 높았고, tyrosinase 억제효과도 $37 \%$ 의 억제율로 가장 높게 나타났다. 감잎 추출 물로부터 tyrosinase 저해 활성 물질을 정제하기 위하여 Sephadex LH-20 column과 MCI-gel CHP-20 column을 이용하여 gradient로 용출한 결과 tyrosinase 저해 활성을 가지는 2 가지 순수한 compound를 정제하였으며, 정제 된 2가지 compound를 구조 동정한 결과, (+)-gallocatechin과 prodelphinidin B-3이었다. 정제물의 tyrosinase 저 해활성을 측정한 결과 (+)-gallocatechin과 prodelphinidin B-3는 29.5, $40.2 \%$ 의 저해활성을 나타내었으며, melanoma 세포에서의 멜라닌 생합성 저해효과를 측정한 결과 (+)-gallocatechin과 prodelphinidin B-3는 각각 32.5, 46.7\%의 저해활성을 나타내어 멜라닌생성억제효과가 매우 뛰어남을 알 수 있었다. 정제된 미백물질을 이용하여 제조한 essence 제품의 안정성을 살펴본 결과, 미백 essence제품의 $\mathrm{pH}$ 는 $10,000 \mathrm{ppm}$ 의 농도에서 $4.90 \sim 4.95$ 였으 며, 점도는 $23,000 \sim 26,000 \mathrm{cP}$ 로 60 일 동안의 저장기간 동안 큰 변화를 나타내지 않았다. 일반적 보존 시험인 온 도에 따른 안정성과 광안정성(인공광, 자연광) 검사에서도 안정하였으며, 특수, 가혹 보존 시험인 온도순환에 따 른 안정성 검사에서도 상의 분리와 변색, 변취 없이 모두 안정함을 확인할 수 있었다. 